\title{
Toward a precarious projectariat? Project dynamics in Slovenian and French social services
}

\author{
Ian Greer (Cornell), Barbara Samaluk (Greenwich), and Charles Umney (Leeds) \\ icg2@ cornell.edu
}

Forthcoming in Organization Studies, August 2018

\begin{abstract}
Project organization is used extensively to promote creativity, innovation, and responsiveness to local context, but can lead to precarious employment. This paper compares European Social Fund (ESF)-supported projects supporting 'active inclusion' of disadvantaged clients in Slovenia and France. Despite many similarities between the two social protection fields in task, temporality, teams, and socio-economic context, the projects had different dynamics with important implications for workers. In Slovenia project dynamics have been precarious, leading to insecure jobs and reduced status for front-line staff; in France, by contrast, projects and employment have been relatively stable. Our explanation highlights the transaction, more specifically, the capacity of government agencies to function as intermediaries managing the transactions through which ESF money is disbursed to organizations providing services. We find that transnational pressures on the
\end{abstract}


state affect its capacity as a transaction organizer to stabilize the organizational field. In Slovenia, transnational pressures associated with austerity and EU integration have stripped away this capacity more radically than in France, leading to precarious project dynamics and risk shifting onto project workers. 


\section{Projects and precarity}

This paper examines project organization in social services. Often studied in high-tech, media, professional services, construction, and infrastructure sectors (Sydow et al, 2004; Bakker et al, 2013; 2016), projects have become common in government-funded social services. The shift toward project work with clearly defined 'time, task, and team', known as 'projectification' (Lundin et al, 2015; Munck and Wolf, 2017; Godenhjelm et al, 2015), has consequences for workers, including legitimizing 'extreme work' characterized by job insecurity and long hours (Peticca-Harris et al, 2015). Precarious work, defined as work that shifts risks onto workers (Kalleberg, 2009), is a growing problem in Europe well beyond social services (Doellgast et al 2018) that projectification may exacerbate. Organization studies has only begun to examine the effects of projectification on workers (Lundin et al, 2015), with projects in social services attracting little attention.

Social service projectification has not produced a uniform trend toward precarity, but the reasons for variation are poorly understood. To address this gap, we examine social services in two countries funded by the European Social Fund (ESF). In line with ESF requirements, this work is projectified, with clearly defined timelines, teams, and, tasks, the latter aimed at integrating marginalized individuals into society by improving their labor market access, a policy agenda called 'active inclusion' (Zimmermann, 2016; Keune and Payton, 2017). 
We compare France and Slovenia because we observe a puzzling difference. Project dynamics exhibit greater precarity in Slovenia than France (Samaluk, 2017; Schulte et al, forthcoming). The risks of project failure in Slovenia are shifted onto workers through job insecurity and weakening professional status.

This difference is puzzling, because these countries have numerous institutional similarities. Organizations in the French and Slovenian social protection fields ${ }^{1}$ fulfil similar tasks, partly due to the shared funding stream, the ESF. As Eurozone members, however, these countries face an austere macro-economic environment that limits social spending (Blyth 2013), making resources scarce for social service providers. Both countries have developed strong social work institutions, which in Slovenia continued under socialism (Zaviršek, 2008). They have a family resemblance as 'Bismarck-type' welfare states. Unlike 'Beveridge-type' systems such as Britain, these two governments have lacked a monopoly over service provision and funding (Palier, 2010), and unlike other postsocialist countries, Slovenia has retained corporatist governance of work and welfare (Bohle and Greskovits, 2008). The importance of skilled social workers, nonprofit service

\footnotetext{
${ }^{1}$ This denotes a subset of social services that assists vulnerable groups often by attempting to overcome clients' social marginalization. In Slovenia this field is called socialno varstvo and in France insertion sociale. 'Active inclusion' is part of a broader shift in the task in a work-first direction: prioritising moving jobless people into, or closer to, paid work.
} 
providers, and corporatist governance are among the reasons why work-first social policies have had comparatively weak traction in both countries.

What explains the emergence of a precarious projectariat in Slovenian social services but not their French equivalents? Our explanation highlights transactions, whereby a service provider delivers a service in exchange for money from a public funder (Le Grand, 2003). States - including elected officials and public administration - act to structure organizational fields, especially in social services (Van Gestel and Hillebrand, 2011). The provider organization is usually a public-sector or non-profit agency employing staff to carry out project tasks. Where providers are outside the public sector, the state's main tool for structuring this field is the transaction: it defines tendering processes, selects providers, monitors performance, and pays providers. The relationship among funders and providers varies widely. They can take the form of non-hierarchical local networks, marketlike price-based competition, tight state administrative control, or a combination (Jantz et al 2018; Greer et al 2017). In the EU the organization of transaction in social services is further complicated by EU governing mechanisms demanding fiscal discipline and specific policy approaches supported through ESF projects.

Empirically, this paper contributes to the literature on projectification by exploring a new context, the social protection field in two EU countries, and examining a key problem 
raised in organization studies literature: the precarity (or stability) of project dynamics. Our main theoretical contribution to this literature is to specify the organization of the transaction as a critical factor shaping the organizational fields in which projects are situated. The state's ability to stabilize this organizational field depends on its capacity to organize transactions. In Europe, this capacity has transnational influences, including austerity and European integration. Differences in this capacity explain the differing precarity of project dynamics and the degree to which projects shift risks onto project workers.

The next sections present our theoretical and methodological approach, contextualising our empirical investigation. Then we present our empirical cases, showing how in Slovenia, austerity and EU integration pressures reduced the state's organizing capabilities, forcing hurried changes in response to ESF conditionality, leading to greater project precarity. In France, transactions evolved through long-standing cooperation between public funders and local providers, which stabilized the organizational field and protected project workers. We conclude with implications for the literature on projectification and some potential implications for two branches of institutional theory that have shaped organization studies debates on projects, namely transaction-cost economics and field theory. 


\section{The consequences of projectification in social services}

'Projectification' describes a trend toward clearly defined tasks and worker roles and explicit temporariness. Midler (1995) coined the term to describe a shift toward project work in a large firm, and others adapted it to the public sector context (Godenhjelm et al, 2015; Munck and Wolf, 2017). In social services, project dynamics are often precarious, leading to heightened insecurity and weakened professional status for workers. Why is this? Organization studies writers have developed sophisticated explanations referring to task, temporality, roles, and local or national socioeconomic context (Bakker et al, 2016; Bechky, 2006; Christopherson, 2002; Whitley, 2006). But in social services these parameters are themselves shaped by the actions of the government funder, a 'project organizer' (Sydow et al, 2004) whose importance stems from organizing the transaction what we call a 'transaction organizer'. In this section we review literature on precarity in social services, evaluating possible explanations from organization studies and outlining our explanation centered on the transaction.

Project organization and precarity in social services in Europe 
The justifications for project organization in social services are similar to those in the private sector: the need for innovation, context-responsiveness, and flexible resource deployment (Sundin et al 2015; Munck and Wolf, 2017). Many countries organize social services as projects, receiving also temporary and conditional ESF funding to address specific needs (Finn, 2015; Fretel, 2008). Following the EU's definition of 'active inclusion' developed for the current program of ESF funding, the organizational field of social protection should aim at 'enabling every citizen, notably the most disadvantaged, to fully participate in society, including having a job'. ${ }^{2}$

What is the organizational field of social protection? The exact task involved can vary from US or British 'workfare' schemes that punitively enforce short-term employment goals to the French and Slovenian models, where job placement is typically a long-term aspiration rather than a short-term target. The organizations also vary from the large forprofit government outsourcing generalists dominant in Britain, to the large church-affiliated nonprofits that run hospitals, nursing homes, and other social services in Germany, to the small and mostly local nonprofits specializing in holistic services for particular client groups that we observe in France and Slovenia.

\footnotetext{
${ }^{2}$ http://ec.europa.eu/social/main.jsp?catld=1059\&langld=en
} 
The 'active inclusion' task arguably suits project organizing, as a detailed government intervention in a rapidly changing context, where policymakers have little $a$ priori knowledge of implementation by front-line workers in provider organizations (Rothstein, 1998). Policymakers may use projects because they assume permanent public sector institutions to be inflexible or refuse long-term financing of schemes with uncertain outcomes. The ESF reinforces project organization in the social protection field by requiring fixed-term funding agreements.

Project teams mainly include professionals with a social work ethos and extensive task discretion. This reflects the complexity and unpredictability of cases (Lipsky, 1980) and institutional factors like the longstanding tendency in many countries to delegate social services to nonprofits (Fretel, 2008). While these organizations lack traditions of lifetime employment, non-profits still generally offer more stability for staff than for-profits (Greer et al, 2017).

Employment relations literature shows that project dynamics matter for social service workers. Compared to counterparts in permanent public-sector organizations, workers in outsourced public services face job insecurity, work intensification, and diminished institutional protections (Baines, 2004; Cunningham et al, 2011). Outsourcing and privatization can increase pressure on staff to hit targets, reducing service quality for 
clients with complex needs (Baines, 2004; Greer et al, forthcoming). These pressures can devalue social service professionals, making them replaceable by lower-paid workers with weaker qualifications (Ranald, 2002). They become 'precarious' in that they bear the risks of project failure more than traditional public-sector workers.

In Europe, the field of social protection is profoundly affected by transnational factors. Austerity is among the policies EU institutions and states deployed following the 2008 crisis (Umney et al forthcoming). It has had a profound effect on these services, by prolonging the crisis and by restricting government debt that could have funded services to address the resulting social needs (Blyth, 2013).

These services are also affected by the redistribution of authority by the EU from member states, upwards (to the European Commission) and downwards (to municipalities and regions) (Hooghe and Marks, 2001). As the main EU resource for these services, ESF match-funds initiatives that fit its defined policy framework (Verschraegen et al, 2011). It has evolved into a 'multifaceted governance instrument' that uses funding conditionality to advance agendas like active inclusion, which may be unfamiliar or unpopular at national level (Zimmermann, 2016). Conditionality and surveillance of countries' fund usage has intensified post-crisis (Huguenot-Noel et al, 2017). Samaluk (2017) shows that in Slovenia, ESF conditionality has led to the downloading of risk onto front-line project workers. 
The impact of EU conditionality, however, varies widely, reflecting (among other things) political concerns and national fiscal situations (Zeitlin and Vanhercke, 2017). The concrete meaning of 'activation', for example, varies. Under rightwing governments in Britain since 2010, the ESF has supported the Work Programme, a minimalist form of support for disadvantaged people, and the Troubled Families Programme, a scheme that targets jobless families to tackle alleged criminality and anti-social behavior. In France and Slovenia, by contrast, it has funded less punitive schemes. ESF participation has pushed local actors towards 'activation' discourses and practices in various ways, especially where local contexts have hitherto resisted them (Gerven et al, 2014). Some organizations may be more changed by ESF participation than others, reflecting individual preferences (e.g. resistance to increased administrative workload) and the reliability of existing national funding (so-called 'integral funds' that are combined with ESF) (Zimmermann, 2016).

Organization studies and the nascent marketization literature can help explain this variation.

\section{Project dynamics in organization studies}

Over time, project organization can destabilize the organizational field of social protection leading to a shift of risk onto workers. As organization studies shows, precarious project 
dynamics matter for organizations and workers. Some large firms organize work in-house as projects, while others are created exclusively for a single project (Sydow et al, 2004); some firms staff projects by buying-in expertise temporarily or by redeploying staff internally (Whitley, 2006); some project work is repeated and other projects are one-off (Grabher, 2004). The literature suggests several reasons why project dynamics might be precarious.

One starting point is that some tasks are suited to precarious project organization. Stinchcombe (1959) argues that cyclical fluctuations in construction work created a need for non-bureaucratic organization structure, specifically projects. Whitley (2006) argues that project-based firms are likely to be 'precarious' when they produce 'singular and risky outputs'. For Grabher (2004), the search for convention-defying original knowledge requires 'disruptive learning regimes' (presumably with low job security), as in London's advertising industry.

Organization studies scholars show how institutional context shapes projects. Typically institutions are used to explain differences across space that are stable across time, which enable particular kinds of work, for example, by generating skills and knowledge in a particular place (Grabher, 2004; Whitley, 2006; Mueller, Pemsel, and Shao 2014). Christopherson (2002) argues that employment relations institutions can mitigate 
precarity, where they enable project workers to exercise a high degree of collective power. However, she also shows how the deregulation of product and labor markets can undermine this power, permitting low-cost production sites where work is more precarious. Lundin et al (2015), by contrast, argue that projectification per se makes it difficult for European institutions to provide stability because of increased worker mobility.

Temporality is another factor. Timeframes may determine project flexibility and scope for innovative thought within them (Bakker et al, 2016); project time horizons need not be of shorter duration than those in permanent bureaucratic organizations, given the annual budget cycles of the latter. Uncertainty about timeframes is an important source of precarity for project workers (Karmowska et al, 2017), although informal ways of extending timeframes through social contact and networks may counteract this. Dille and Söderlund (2011) note that institutions can determine the speed and cycles of projects, and that institutional differences can make it difficult to synchronize different actors in a project. Specified end-dates do not necessarily signal an end to work on a project, which may be sustained by enduring funder-provider relationships (Lithgart et al, 2016). Project work may also have continuity by virtue of the reproduction of stable roles across different tasks (Beckhy, 2006). 
Hence the task, institutions, temporality, and project roles offer explanations for variation in project dynamics in organization studies. But in social services we must consider another dimension: the role of the state in structuring the organizational field.

\section{Transactions and project dynamics}

Our approach to the state's role in this organizational field centers on its management of transactions and organization of markets. As Ahrne et al (2015) argue, markets are often organized by some agent in a non-spontaneous way, typically with an eye to ensuring stability in an organizational field. We can therefore expect to observe some effort to mitigate project precarity. Social services are an illuminating context to examine market organizers because of the decisive role of the state in funding projects and organizing transactions.

By separating purchaser and provider, governments can organize transactions between them with aim of optimizing cost, quality, and responsiveness. Government bodies define incentives and provide resources to varied providers (Le Grand, 2003). These transactions vary widely: some are highly competitive and price-based, while others involve long-term ongoing cooperation with price a secondary concern (Greer et al 2017). Under different kinds of transactions researchers have observed different patterns of 
interorganizational relationships: intense price-based competition favors commercial organizations hyper-responsive to incentives to delivering quantitative results (Greer et al forthcoming), whereas relatively uncompetitive transactions can allow networks of nonprofits to cooperate driven by a professional social-work ethos (Jantz et al 2016; Schulte et al forthcoming). Competition in social services tends to disrupt existing organizational networks (Hipp and Warner, 2008), especially those with a social-work ethos (Greer et al forthcoming).

In social services, the nature of the task has been reshaped by the transaction. This is the reverse of transaction cost economics, which sees the governance of transactions as shaped by the nature of the task (Williamson, 1985). Depending on the task, it is argued, transactions may be highly competitive and arms-length and others may involve more intensive interorganizational relations. In social services, however, the transaction has been deliberately used to re-engineer services. Unlike grants, which allow for co-production of services between funder and provider, public procurement law requires most funders to define them in a detailed way a priori. This makes it difficult for provider organizations to innovate based on knowledge gained during the contract (Greer et al, 2017, chapter 6) and disrupts the inter-provider relationships needed for some services (Hipp and Warner 2008). Price-based competition can also lead to the institutionalization of adverse selection in 
commercial service providers (Greer et al forthcoming). The European level creates further complications through periodic changes in priorities, leading to negotiations with member states over how to deploy funds.

Project timeframes are also shaped by the transaction. Most obviously, short-term contracts lead to short projects. But governments can also increase temporal uncertainty by opening markets to new competitors who may compete to take over if projects are renewed, or by introducing discretionary extension options (Greer et al, 2017).

The transaction also influences worker roles within provider organizations. Public funders can decide whether to require formal social work qualifications among project staff. In German job-placement services, the absence of such rules for some services enabled providers to employ less qualified staff with lower job security than those working under direct public purchasing (Greer et al, forthcoming).

Finally, the transnational dimension of transactions shapes local context. This is particularly important in European social services. National governments become intermediaries in the administration of funds, negotiating with the Commission over whether their priorities match EU concepts such as 'active inclusion'. In France these intermediaries are a web of regional and local institutions including 'deconcentrated' regional offices of government ministries, reinforcing longer-term trends towards 
administrative decentralization (Bezes and Le Lidec, 2011). In Slovenia, intermediaries are emerging but remain mostly centralized within government institutions (Samaluk, 2017). Under austerity pressures, ESF moneys are assuming a greater share of social service spending. As we will show, using this money places severe administrative demands on national governments and project workers.

\section{Our argument}

Explaining this contrast requires understanding the administrative capacity of government funders as project organizers, or, more specifically as transaction organizers. Transaction organizers often manage project transactions with an eye to stabilizing the organizational field of service providers; but the Slovenian case reveals that they are not always able to do so. Without a transaction organizer characterized by strong administrative capacity, project dynamics become precarious, leading to a shift of risk onto project workers.

Transaction organizers often resemble what Lundin et al (2015) call 'projectsupporting organizations': they are permanent organizations with stable organizational features which also contain regularly changing projects. In both countries, funders are public-sector organizations that have been reconfigured to act as an intermediary between Europe and localities, including coordinating local networks of service providers and 
distributing funds. These are typically referred to as 'purchasing agents' in public administration literature, and the organizational fields they engender as 'quasi-markets' (Le Grand 2003).

The methods for distributing funds are a powerful tool to stabilize organizational fields. The providers of these services resemble what Lundin et al (2015) call 'projectbased organizations', since project work accounts for most of their activity. Because project funding is always temporary, these organizations and their staff are vulnerable to funding loss. In this paper we focus specifically on ESF-supported project-based organizations providing social services. Transaction organizers can mitigate (or exacerbate) these problems through decisions about how much competition there should be with nonincumbents, how decisive the price mechanism should be in selecting providers, the project timeframe, and the detail in which the service is prescribed (Greer et al 2017).

Not every transaction organizer can manage transactions effectively. One problem highlighted by ESF evaluators has been timing. The launch of new ESF-funded programs in the accession countries, took place under additional rules, regulations, and checks, and this was 'made even more complicated by insufficient experience, lack of administrative capacity and internal reorganizations processes of public administrations that undermine administrative continuity' (Bubbico and De Michaelis, 2011: 6). Slovenia entered the EU in 
2004, immediately before a change between ESF 'programming periods', whereby the European Commission increased the administrative requirements for launching new programs for 2007-2013. The problem was similar to Dille and Söderlund's (2011) notion of a 'temporal misfit'; governments in new member states were not adapted to the EU's budget cycles. A second problem is austerity, which imposes resource scarcity on both transaction organizer and service provider. It reduces the transaction organizer's ability to mitigate problems, create programs, and pay staff, and creates even greater dependence on the ESF.

Both of these problems emanate from the transnational level. Transnational pressures increased after the economic crisis, when EU governance demanded stricter fiscal discipline and introduced a more prescriptive approach to social policy reform. While the post-crisis need for expanded social infrastructure increased, Slovenia had to reduce spending for social protection programs and imposed strict limits to public sector hiring which were less severe in France. Moreover, Slovenia is characterized by less generous social protection spending (17.4\% of GDP) than France (24.5\% of GDP) $)^{3}$. These factors increased Slovenian dependence on the ESF, thus opening social protection field more dramatically to new participants, approaches, and organization types. 
The conditions under which project dynamics are precarious thus hinge on the transaction. Past research finds that transaction organizers often intensify these problems by promoting intense price-based competition at the level of the transaction (Greer et al, 2017). For the present comparison the transaction matters in a different way: the transaction organizer is not deliberately disrupting the field by promoting competition, but rather failing to stabilize organizational fields where there is relatively little competition.

\section{Methods}

Our research design has inductive and deductive elements. Inspired by the grounded theory tradition, we used qualitative interviews to generate unexpected insights (Glaser and Strauss 2017). From past studies, we understood the basic features of the task, transactions, and socio-economic context. We discovered inductively in early interviews the features of project organization, its relationship with the transaction, and the differing levels of precarity between the two cases. Initial interviews were completed, translated and Englishlanguage notes coded openly. After discussing the material and the coding scheme, we conducted further interviews. Based on further discussion of codes and findings, we developed a common framework, whose characteristics structure our empirical presentation 
and comparison: (1) the pressures acting on states; (2) state capacity to organize transactions; and (3) the precariousness of project work. We used these for a final coding of the English-language transcripts and notes.

Inspired by King et al (1994) we sought to explain the main outcome - precarious versus non-precarious project dynamics - by examining cases that differ in terms of it, but do not differ in terms of various other variables that might matter. Beyond the shared issue of projectification, there were important similarities between the cases in terms of institutional context, task and roles. Some obvious differences, such as the size of the country, age of the state, and post-socialist heritage, did not significantly affect our outcome.

We derive our analysis from qualitative interviews with policymakers, workers and managers at provider organizations, and other key informants (trade unionists, provider umbrella bodies and academic researchers), which provide specialized knowledge concerning a complex and changing organizational field. Participants were recruited through cold-calling and office visits, with further snowball sampling based on these initial contacts. As table two shows, this included 36 participants in each country, mostly interviewed one-on-one. 
(Table 1 about here)

The size difference posed a challenge for research design. While our Slovenian interviews spanned the country, we concentrated on one specific French department, SeineSaint-Denis (population 1.6m). This is a low-income area with elevated spending on regeneration schemes, including ESF-funded programs to assist socially marginalized groups. This enabled a qualitative focus on the governance of ESF projects as rich as the Slovenian data, which a nationwide investigation would complicate. The workers we met in Seine-Saint-Denis may be in a less precarious situation than their counterparts elsewhere in France given the high need and spending locally and the strong tradition of leftwing local government, but it is difficult to say this conclusively without further research. Our purpose is to compare two in-depth studies to illuminate causal mechanisms, with the French case being representative of Seine-Saint-Denis rather than the entire country.

\section{Slovenia}

Pressures on the state

In Slovenia, projectification has taken place as the main transaction organizer, the Ministry of Labor, Family and Social Affairs (MLFSA), has seen its capacity to organize social 
service project transactions sharply diminished. This has weakened its grasp over the organizational field of provision, which has also become less stable. Transnational forces have played a central role, especially the post-crisis shift in EU governance towards stricter fiscal discipline based on binding Country Specific Recommendations (CSRs) and ESF conditionality (Keune and Payton, 2017). This shift happened alongside negotiations over the 2014-2020 financial perspective, leaving national negotiators unprepared and surprised at the force with which EU requirements were imposed:

The EC was very cunning. . . like other countries also Slovenia did not want active employment and social policies to be governed by the EU policy, because we wanted to keep it under our sovereignty. . . I was very shocked in these negotiations... These CSRs are no joke anymore, because they will squeeze you, no matter how illogical they are (SL policymaker 2).

ESF moneys have increasingly come to fill domestic funding gaps, increasing ESF influence in policy. Already the previous perspective had brought substantial policy reform and institutional adjustment, which were unsustainable under austerity conditions and given the recurrent change pressures imposed by ESF-driven 'modernization'. National funders were discouraged from continuing funding ESF projects that were covered under the previous financial perspective and which could not, under austerity, be covered by integral funds: 
Previous experience was that [coordinators at the ministry] would do things their own way ... During negotiations [for the 2014-2020 perspective] the Slovenian side proposed that we continue financing successful innovative projects, which used to be financed within active labor market programs and social entrepreneurship ESF schemes . . But they said: "No, this is not the purpose." There is a logic behind it that you should [use this money] to set up something, try something new and then it should become part of the system (SL policymaker 3).

Difficulties in meeting the new conditions weakened Slovenia's ability to maintain existing projects, forcing adoption of new active inclusion policies. Increasing dependence on EU funds generated competition among ministries, which sought to associate their own briefs with the active inclusion agenda.

Inter-ministerial competition and compliance with preliminary ESF conditions caused delays in absorbing funds. The 2014-2020 funds will be absorbed in 2017-2022. These delays intensified pressure for rapid integration of active inclusion with social policy. For instance, MLFSA gave a think tank only three months to prepare guidelines for implementing active inclusion. One participant explains the difficulties of operationalizing ambiguous new concepts: 
I think it's good for Slovenia to get new concepts and approaches, although sometimes we cannot distinguish between what are only buzzwords... When we looked up the meaning of social activation, there was no clear definition, everywhere it says: "This is not only aimed at labor market integration, but more at social integration, but it's beneficial if it results in employment." Thus very unclear and practices are even less clear (SL policymaker 3).

The Slovenian adaptation of active inclusion followed models from Western Europe, prioritizing 'employability' and tightening connections between social support and the job search for clients with complex issues (Trbanc, 2015). Slovenia thus faced many challenges as the recipient, rather than the shaper, of EU policy concepts.

Under the previous financial perspective the ESF policy agenda had already brought new organization types to the Slovenian social protection field, namely 'social enterprise', which allows traditional non-profit organizations to receive initial funds to establish new entities that undertake economic activity (Commission, 2014). This organizational concept was not well adapted to the Slovenian context. A $2011^{4}$ law transposed EU-propagated definitions despite the long existence of disability enterprises and care work centers

${ }^{4}$ https://www.uradni-list.si/1/content?id=102703 
performing similar functions in Slovenia. 'Social entrepreneurship is only a modern term of what we've always had in Slovenia. ... when this concept was implemented we should have established better its local meaning ... that could support already-existing local 'social enterprises" (SL policymaker 2). The ESF definition prompted the emergence of a new organization type prioritized for funding support, threatening existing non-profits and opening social policy provision to new actors (Samaluk, 2017). Many small nonprofits lack the means to pre-finance projects (which the ESF requires), let alone maintain them after ESF funding expires. Consequently, many established non-profits had refused to apply for ESF-funded projects for the establishment of social enterprise under the previous perspective or struggled to survive after funding ceased (Samaluk 2017).

Austerity pressures, rapid EU integration, and the demand for new organization types combined to put extreme pressure on Slovenian state, reducing its capacity to organize transactions in social services, as we show next.

\section{Weak capacity to organize transactions}

Slovenian service provider organizations fall into two broad types. Social protection has traditionally been provided by local public-sector Centers for Social Work (CSWs), dating to former Yugoslavia (Zaviršek, 2008). These are supported by various non-profit 
organizations, which emerged during the 1990s to address neglected social needs (such as disability, mental health, domestic violence and equality struggles). Employment services date back to 1900 and are provided by the Employment Service of Slovenia (ESS), also a public-sector organization supported by non-profit and private service providers, which provide labor market integration projects with weaker public oversight than in social protection. Active inclusion seeks to bring these actors closer together, requiring social protection providers to focus on preparing users to 'return' to ESS as jobseekers. This ESFdriven merging of previously separate policy areas further strained Slovenian state capacity.

ESF funding is managed mainly by a central government ministry, MLFSA. Most active inclusion projects fall under its remit, but the central ESS office also receives ESF funds to manage tenders for services provided by NGOs. Under ESF guidance, the ESS office has established a project office responsible for coordinating ESF-funded projects, but no similar project-supporting organization yet exists in the social protection field, which until recently was less directly shaped by the active inclusion agenda. This presents problems for the administration of social protection programs: 'Great, programs yes, but without structure that will manage this, there's no chance ... The ministry is not able to do that. We hardly managed a couple of tenders, which were worth $€ 50$ million at most, let alone the current $€ 200$ million' (SL policymaker 2). 
Moreover, there are problems finding provider organizations to deliver 'active inclusion' services. Public-sector CSWs were reluctant to perform the task, seeing themselves as ill-adapted to the objective. Although nonprofit incumbents in the social protection field were skeptical of the active inclusion agenda, a lack of integral funds pressed them to explore alternative funding sources to develop additional services: '[We apply for EU projects] because this is the only way to do something more apart from already established things' (SL provider1).

These problems were debilitating for transaction organizers, which lacked willing service providers for the new agenda. ESF funding was used to encourage provider organizations to embrace the ideas of active inclusion. 'CSWs...did not want to deal with these users, mostly arguing...that they do not have appropriate programs. Then we [the ESS] said: "We will prepare a pilot project and this might encourage them"” (SL provider 5). In the pilot, a tender for NGOs was issued to assess the 'employability potential' of long-term welfare recipients: 'The tender was very broad...they wanted to have providers in all regions. Somewhere there were many applicants and they could choose and in other they could not. Somewhere there was only one applicant and this one was chosen.' (SL policymaker 3). Another, in Spring 2017, for long- and short-term projects had similar 
problems: for short-term projects, the tender had to be adapted to encourage more applicants, and for long-term ones calls had to be repeated to find applicants in all regions ${ }^{5}$.

ESF weakened regulatory requirements, such as professional verification by the Social Chamber ${ }^{6}$, in stipulating that funding be open to all providers. Moreover, aside from reluctance to embrace the active inclusion concept, many organizations could not meet prefinancing requirements. Consequently, most organizations that did apply under the pilot were those that also provided high-threshold ESS-managed projects, which are subject to weaker regulatory oversight (Lebar et al, 2014).

The evaluation [of the pilot] showed that many providers did not know the target groups ... in one region a driving school ended up being a provider, because it was the only one that applied for this region...It was very clear that providers did not know what to do with these people, and there were no conditions regarding exits.... They [ESS] have some providers, which are not highly regarded by the CSWs (SL policymaker 3).

\footnotetext{
${ }^{5}$ http://www.mddsz.gov.si/si/o_ministrstvu/javne_objave/javni_razpisi_in_javna_narocila/?tx_t3javnirazpis _pi1\%5Bshow_single\%5D=1052

${ }^{6}$ The Social Chamber of Slovenia is a central professional social welfare association preparing regulations and standards governing social welfare services and qualification standards for different activities and for the assessment of professional work.
} 
Incumbent service providers were thus marginalized vis-à-vis new entrants whose management and staff lacked a social work orientation. The rapid implementation of ESFfunded pilot schemes also created confusion around providers' tasks and administrative obligations:

The [pilot] project was too quickly set up, because the funds needed to be used. It was not thought through, which also affected users' rights... These people were forgotten from institutions for 15 years and now they were expected to be present every day 100 per cent. So this was one problem. The sick leave was not defined. There was problem with travel expenses... Due to that our work was very difficult over this four month period...every time we saw each other we discussed money issues. You are confronted but you cannot do anything, but direct them to CSWs. And they didn't trust them. It was crazy! (SL provider 12). The ESF-supported implementation of active inclusion weakened the state's capacity to organize transactions in the social protection field and pushed providers to engage in ill-defined experimental projects. Consequences include the lack of management structures, difficulty in finding willing providers, unclear and changing obligations, and the watering-down of regulatory oversight. 


\section{Towards a precarious projectariat}

Disrupting the social protection field has increased the precariousness of project work. Workers have less access to permanent jobs, and their professional status is threatened, particularly in terms of pay and monitoring at work. This applies to for-profit and nonprofit project-based organizations, but also public-sector providers, where front-line service and coordination work has shifted from permanent to project-based organizations.

Under the 2007-2014 financial perspective, public-sector jobs in the CSWs and ESSs funded by ESF were turned into temporary project-based ones (Samaluk, 2017). While austerity prevented the creation of permanent jobs, CSWs received an additional 62 ESF-funded temporary project workers. These temporary posts were rendered attractive by higher pay and the promise of future permanent contracts. These promises have not been fulfilled: all posts created under the previous financial perspective were terminated at its end. There were not enough integral funds, and the second perspective imposed different priorities that made these positions ineligible for funding. The 52 current project workers delivering active inclusion have received similar promises, but their access to permanent contracts depends on future ESF priorities. The combination of changing ESF priorities and austerity has thus brought insecure project-based organization also into public sector provision. Continuing recruitment caps are especially problematic for young and 
unemployed professionals, whose entry into the public sector is limited and granted only intermittently through temporary ESF-funded projects. Moreover, the ESF has unreliably financed social care internships that allow young graduates to gain experience to qualify for a professional license, leaving many young graduates without an essential requirement to obtain permanent professional jobs (Samaluk, 2017).

Among non-profit, traditionally project-based organizations, some additional stability arrived after 1998 when MLFSA began offering five-year instead of three-year contracts. While salaries within non-profits are linked to projects, they are based on collective agreements and laws defined within the public sector ${ }^{7}$. When funded integrally, social protection workers operate under the professional standards of Slovenia's Social Chamber $^{8}$. But the volume of integral funding has been cut under austerity:

I am linked to a project financed by the MLFSA. This is a 5-year project also verified by the Social Chamber...And we need to apply for this project and verify it every 5 years...We are all dependent on project funds, so those of us who are more long-term are normally on more stable projects (SL provider 4).

High regulatory requirements also limit competition for future tenders, reducing uncertainty on integrally funded projects. Nevertheless, while permanent contracts are favored for the

\footnotetext{
${ }^{7}$ Article 35 of the Law on Humanitarian Organizations: http://www.uradni-list.si/1/content?id=45459

${ }^{8}$ https://www.szslo.si/verifikacija
} 
sake of simplicity, one NGO manager told us: "everyone knows that this permanency depends upon projects...For instance, next year one project expires and we are applying [to renew it]. We will most probably get it, but nothing is certain. So if we are unsuccessful four people lose their jobs and we have to close our daily center" (SL provider 3).

The decline in domestic funding also increased salary volatility in integrally funded projects, which become increasingly dependent on alternative sources of funding:

The salaries are defined according to the amount you can apply for in a specific project. We have certain rules regarding that... which are grounded in rules set for the area of social protection...However there is a problem, while due to the crisis the ministry has yearly decreased...[integral] funds, which also cover salaries...we try to keep salaries stable, but not always, some had to decrease...We try as much as we can by drawing from other funds (SL provider 7).

While in 2016 domestic funding started to return to pre-crisis levels (Smolej-Jež et al, 2017), ESF-resources have provided an ever-higher proportion. Where ESF funds are concerned, project dynamics are more precarious. Tenders are open to a more diverse range of actors, meaning professional standards are of secondary concern and collective agreements over salaries are not necessarily applied. This has encouraged work intensification and the hollowing out of established professional roles. Project workers 
perceived a devaluation of the social work ethos through increasingly bureaucratic and illdefined obligations. One ESF-funded project worker describes this experience:

When we had this ESF project, a second-hand shop, which employs our users...it was bureaucratically very demanding, they were exclusively interested in paperwork...One example: we opened a shop and we had this idea to equip it together with users ... The idea was that they are included in the overall process. If you are equipping a shop you need screws to fit in the shelves... we send them the bill and they required additional information, why we need these screws... we send them pictures ... and two pages of explanation. They said that this is not allowed... They were never interested in content only that all the papers were in order (SL provider 8).

Another refers to a previous pilot project:

The project lasted four months, which is quite long, but if you also have to deal with bureaucracy, it is not... There was a bunch of things that were unforeseen...CSWs told us that we should be professional enough to distance ourselves from [users'] social distress. But you cannot, if you work with users for four months three times a week...It affected all of us, we were all under stress. (SL provider 12) 
The responsibility to deliver the ESF-funded activation agenda has thus been downloaded into increasingly high-pressure work in project NGOs: 'There is constant insecurity, working on the edge, on the border, because you never know, if it is going to go through. There is never enough capacity, never enough space...the working conditions are not optimal' (SL NGO provider 9).

With disproportionally large amounts of EU funds available for activation, these pressures will mount on NGO providers. Stagnant integral funding, diminishing publicsector job opportunities and ESF-induced projectification are pushing social work graduates and unemployed professionals into the NGO sector, often for little, or even no pay (Samaluk, 2017). While NGO senior managerial staff contracts are normally linked to relatively secure integral projects, young graduates and unemployed professionals enter either through ESF-funded projects and programs (Ibid). In this context, new entrants are also encouraged to create their own jobs by applying for administratively demanding ESF projects: 'This girl came to me and said: "I would like to intern at your organization" I said: "Great. Look there is a tender out, apply for it. You will take over all the bureaucracy...". I helped her... so she learned a lot of these bureaucratic things' (SL provider 3). This is evidently encouraged by the absence of structural and human resource capacities to manage resources. For instance, the management of ESF-funded internships was reluctantly taken 
by the Social Chamber following pressures from self-organized students demanding paid internships: 'This was a lot of work. At the end Social Chamber prepared the project with the help of three students, who were then fighting [for paid internships]' (SL social work student).

The continuing ESF-driven shift towards activation, combined with austerity pressures, engineers the precarious projectariat: it has intensified work and weakened oversight of qualifications, thus undermining professional statuses and embedding temporary work relationships. Our interviews indicate that the burden of ESF bureaucracy in Slovenia falls disproportionally on young and unemployed professionals, whose job prospects are increasingly dependent on accessing ESF-funded projects. Since ESF projects are a relative novelty in Slovenian social services field and branded as an innovation, they can also be perceived as an attractive opportunity to young or excluded professionals, who are not yet familiar with their bureaucratic burdens or organizations' financial difficulties to turn them into more permanent organizational forms. Without sufficient stable integral funding to turn ESF-driven project work into permanent programs, the insecurity of precarious projectariat is likely to increase. This lack of resources reinforces the state's weak capacity to shape the social protection field via transactions, leaving it particularly exposed to transnational pressures. 
While the established public-sector unions, NGO umbrella bodies, and new movements of precarious and young workers have fought against the disruption of services and jobs and have won some victories, the precarious projectariat remains on the margins of political discourse and the trade union movement, which continues to address its demands at the national government rather than the EU level. More than France, transnational influences undermine the ability of Slovenia's national institutions to protect workers ill-equipped to cope with projectification.

\section{France}

\section{Weaker pressures on the state}

In France, by contrast, weaker transnational pressures and stronger state capacity have permitted stability in the social protection field by allowing the maintenance of stable relationships between funders and long-established provider networks in the face of projectification. The main transaction organizer is DIRECCTE, a "deconcentrated" public agency that administers ESF funding, whose regional branches are directly accountable to central government. Its regional branches manage transactions with provider organizations, but departmental offices exercise some latitude in choosing providers (FR policymaker 1). 
Other transaction organizers are non-profit intermediaries such as PLIE, which distribute funds across groups of municipalities. Typically, PLIE channels funding to finance various individual workers across a network of local providers, charged with delivering a defined service pathway. It also funds specific projects such as 'integration work-sites' [chantiers d'insertion]. DIRECCTE funds provider organizations directly, with contracts normally lasting one year. Fundees are typically paid 18-24 months after the award of the contract. At PLIE, projects can run for up to three years, usually being reassessed after one: if satisfied, PLIE asks that central government requests the release of ESF funds, mitigating the problems pre-financing requirements impose on providers (FR policymaker 4).

These timeframes are no longer than those found in Slovenia. The critical difference is the transaction through which projects are initiated and governed. French funders distinguish between calls for projects [appels à projet] and calls for tender [appels d'offre]. The latter refer to calls for bids following a precise, funder-defined tender. The former, through which most PLIE and DIRECCTE-awarded funding passes, require organizations to define the project they offer, the needs it meets, and measurable objectives, which are then evaluated in relation to funders' perceptions of local needs. Hence, calls for projects imply more autonomy for the provider in defining their intervention, and funders tend to 
rely on this initiative in diagnosing unmet needs. PLIE does issue calls for tenders for smaller one-off projects, which are delineated from core social work functions.

This enduringly high level of provider input is the distinguishing characteristic of the organization of transactions in French activation projects. Pressures associated with EU integration and austerity have been weaker (France still maintains comparatively generous spending on social protection by European standards) and transactions are thus less directly shaped by ESF-defined terms. Nonetheless, ESF conditions and domestic political trends do shape the intervention funded and administrative reporting duties involved. The next section shows why these have been less disruptive in France than Slovenia.

\section{Co-evolution of the transaction}

French funders tend to channel ESF and national funding towards long-established incumbent "project-based organizations" rather than new entrants: longstanding practice is to use EU funds to complement existing activities and support a strong existing infrastructure and approach. This has not been overwhelmed by ESF administrative requirements. While project timeframes may be short, both funders and fundees confirmed that the same structures typically received funding year-on-year, unsurprising given funders' reliance on provider initiative in designing interventions. Unlike Slovenia, where 
the ESF disrupts established networks: 'here there is an associative network that is already very developed, and as a result so established' (FR policymaker 2). While ESF priorities change, funders and providers discussed the integration of new work with existing interventions, rather than disrupting the field through new tenders (FR provider 3). Elsewhere, a manager describes funder-provider dialogue:

So for example, for this year 2015, we must work a lot on the development axis, the environment, for example. We must also work on all that is linked to questions of mobility for young people- national, international- to push them to travel, to discover the outside. We will also work on questions more of professional integration, jobs, lots of things. Voilà! There are orientations which are effectively defined, that we must pursue, and others where we are freer (FR provider 4).

One respondent at PLIE (FR policymaker 4) had previously managed ESF funding in postsocialist countries (not Slovenia) and his comparative experiences proved instructive. He saw these stable funder-provider relationships as distinctively French, noting that it forms an explicit strategy of adapting ESF resources to suit what is already in place, rather than vice versa.

Strict evaluation criteria are not embraced in monitoring the transaction: 'we aren't in a culture of evaluation... putting the associative network into competition would make 
no sense' since providers had evolved over a long period in tandem with local needs (FR policymaker 2). At PLIE, similar comments were made (FR policymaker 4):

[First participant:] With a call for projects we don't really have this notion of creating competition. It exists even so because we'll choose the projects that correspond with ours.

[Second participant:] It's more qualitative...

[Third participant:] It's more about choosing the people with whom we want to work and we work with the same people for several years

When outcomes were assessed, both funders and providers saw room for extensive qualitative discretion, including reflection on contextual reasons why targets had been missed, giving greater latitude to incumbent organizations in justifying their performance (and for funders to extend projects). These services have been criticized in national political discussion for achieving low numbers of job placements, leading to calls from some quarters for more commercial provision and a Sarkozy-era pilot of for-profit operators in Seine-Saint-Denis. Local providers and funders did not trust the new players, and evaluators found that the new schemes were more expensive and no more effective than existing ones (Schulte et al, 2017). After this brief experiment, for-profit firms did not establish themselves as major local players in this field. 
The funders are committed to maintaining the field of social protection in SeineSaint-Denis. The PLIE will, if necessary, advance money from its own budget to mitigate the risks caused by pre-financing requirements. This was one reason given for founding the organization. Similarly, at DIRECCTE: 'we always come to give them a little subsidy... because there are jobs there, and if they do a good job in insertion we can't do without them either' (FR policymaker 2). The active role of funders in maintaining the incumbent organizations with whom they develop and deliver services has mitigated the emergence of a precarious projectariat in various ways.

\section{Absence of a precarious projectariat}

While some interviewees expressed concerns about the 'precarisation' of social work in France (FR NGO umbrella 2), the situation in our research site was comparatively stable. Like in Slovenia, ESF funding has intensified administrative burdens, causing work intensification. However, the emphasis on the quality of relationships between the funder and incumbent providers has greatly mitigated potential consequences.

Managers at nonprofit providers placed great importance on the experience and training of front-line workers (FR providers 2 and 3). Respondents repeatedly emphasized the importance of specific training qualifications and experience profiles, individual 
autonomy and problem-solving in the labor process, and close-knit teams. The extent of this professional autonomy has been examined in greater detail elsewhere (Schulte et al, forthcoming). Front-line interviewees described in interviews how service users' trajectory through activation pathways depended more on individual staff expertise than on funderdefined indicators (FR providers 15-17).

As in Slovenia, administrative workload was increasing, often driven by ESF conditionality. One front-line respondent at a nonprofit asked about bureaucratic encroachment on their labor process referred promptly to ESF: 'it was necessary to have quarantaines of columns, so many lines with accompanied people ... the limitation on autonomy is at that level' (FR provider 12). Our interviewees were in widespread agreement that ESF conditionality had intensified these requirements. At one organization, for instance, ESF record-keeping requirements had led them to introduce an annual weeklong closure of the service to free up time to comply (FR provider 11).

However, the implications of increased administrative burdens for front-line staff had been cushioned. As noted, organizations could typically offer qualitative justifications for shortfalls; this reduced precarity associated with project temporality, since relationships clearly preceded, and extended beyond, specific project end-points (Lithgart et al, 2017). Hence the risks associated with the need to hit funder-defined targets had not translated into 
intense performance management, and job security was assumed to extend beyond existing project timeframes. Several interviewees expressed the belief that providers cannot properly serve service users if staff are precarious themselves. This did not only come from front-line workers; one manager told us: 'we consider that one can't help people in situations of great precarity, one can't fight against precarity, if in our own structures, we have people in situations of precarity' (FR provider 3).

Consequently, staff interviewees tended to feel relatively secure in their work. One described planning his career for 2-3 years in advance, seeing his current position as a reliable stepping stone and opportunity to learn new skills (FR provider 13). Most frontline staff interviewees were hired on permanent contracts, including those working in fairly peripheral roles, such as one tutor who worked at the provider only 2-3 hours per week (FR provider 17). Fixed-term contracts were used primarily fill gaps caused by long-term leave, and were often concentrated in support roles rather than frontline counsellors.

Most insertion workers' terms and conditions are regulated by a national convention which imposes a salary grid, though some organizations had opted out of this (FR provider 3). Unlike in Slovenia, where ESF projects were stimulating new organizations following watered-down regulatory frameworks, professional qualifications remained important, reflected in attempts driven by government to link the salary grid more tightly to 
qualifications (FR provider 15). In France the ESF did not stimulate the kind of innovation that would disrupt national collective bargaining agreements or the professionalization of jobs in the sector; collective agreements remained and formal qualifications were increasingly important for staff:

Because the profession has developed, today to apply for a counsellor's post, you will be asked about experience, or about passing counsellor training, or about having a study level of bac +2 in sociology/psychology. That's the profile which is looked for. 10-15 years ago, without having that profile, you could all the same have a chance to find work in this domain. But since it's evolved a lot, and that they are trying now to put all the [public-sector service providers] on the same level shall we say, bah, there is a collective national contract with a national wage grid (FR provider 10).

Innovation had taken place together with professionalization, which worked against precarity in project work. Respondents, however, did stress that under budget pressures the overall salary levels had declined in real terms, and that the progression from one index point to the next was generally quite modest.

These remarks about France require qualification. While these jobs were relatively stable, many interviewees were worried about austerity pressures and political dynamics, 
and the phrase 'not yet' was a constant theme of interviews. Emmanuel Macron, elected President shortly after our research, announced in October 2017 a 'big bang institutionnel' to restructure local government in the Paris region; 6 departements including Seine-SaintDenis responded by organizing a signature campaign in defense of front-line services. ${ }^{9}$ Worries about insecurity were thus tied less to changes in ESF requirements but domestic politics. One respondent, interviewed in 2012, argued their organization had been defunded for its 'Anti-Sarkozy' stance (FR provider 1). A more recent interviewee argued: 'we are on [permanent contracts], we are stable but at the same time, we have in any case this sword of Damocles above our head... last year we had an economic redundancy simply because one of the actions that we were performing were no longer subsidized' (FR provider 10). In addition, increasing reporting duties for both domestic and ESF funders were leading to a regimentation of the labor process:

We are a bit more watched, and we are asked to make more and more placements. So inevitably the figures are more watched than before. So we will have more of these objectives about quantity in the figures rather than quality... Today we have a bit of freedom... Sometimes I have a meeting with [a user], it can take only ten minutes because he's already well advanced in his project, we can solve two or

${ }^{9}$ www.seine-staint-denis.fr/Grand-Paris-les-departements-d-ile-de-france-font-front-commun-contre-unbig.htm 
three things very quickly, it takes ten minutes. But sometimes the meeting can take an hour, because the person has a big problem. So we work a little bit in our own way in spite of everything... But we recognize all the same that, more and more, that is changing. In other words... perhaps in some years we'll be told "an interview is 30 minutes and no more (FR provider 8).

The concern was that cost pressures would jeopardize qualitative elements of service provision, leading to reduced focus on track record and expertise of incumbent organizations and a diminishment in workers' professional status. Our interviewees, however, attributed this to national political trends rather than ESF conditionality. Indeed, the umbrella body for French associations saw its lobbying efforts in Brussels as highly effective in preventing a new procurement directive from disrupting French funding arrangements (FR NGO Umbrella 1). If a precarious projectariat is to emerge in the French social protection field, it will likely be catalyzed by domestically driven austerity and new public management pressures, as it has already in the public employment service Pole Emploi (Lavitry, 2015). The creation of a precarious projectariat, however, has been obstructed in our French research site by transactions that favor incumbents and cement their relationship with the funder in the social protection field. 


\section{Conclusion}

This paper asks: under what conditions does project organization produce precarity for front-line workers in social service projects? Although the precarity of projects is an important theme in the organization studies literature on projects (Graher, 2004; Whitley, 2006), few studies have examined how project organization affects worker precarity (Petucci-Harris et al, 2015). We examine this question in a sector that has previously been overlooked in literature on projects, social services, where precarity is a crucially important concern of project organizers and workers. European funding is based upon project organization and is therefore an important driver of projectification in this context (Samaluk, 2017; Verschraegen et al, 2011; Zimmermann, 2016). Our first contribution is an empirical examination of project dynamics and its consequences for workers in a new and important setting.

Our theoretical approach is distinctive, because it emphasizes the transaction as a key determinant of project dynamics. Where states are capable of acting effectively as transaction organizers, the drivers of precarious projectification can be mitigated, including those stemming from the transnational level. The transaction has been neglected in organization literature, which has tended to focus on factors such as task (Whitley, 2006), roles (Bechky, 2006), institutional context (Christopherson, 2002; Grabher, 2004), and 
timeframe (Bakker et al, 2016) in explaining project dynamics. Our approach is consistent with the growing recognition in organization studies that markets themselves are organized in a non-spontaneous way by particular actors (Ahrne et al, 2015). Indeed, Sydow et al's (2004) proposal for an actor-centered approach to project organization is readily transferable to the transaction: in social services, the government funder acts a transaction organizer. We argue that project dynamics in the "project-based organizations" that employ staff to deliver services depend on the administrative capacity of "project-supporting organizations" that organize transactions (Lundin et al, 2015). Our second contribution is thus to show how organization of the transaction can worsen or mitigate precarity in projectified organizational fields.

We argue that the key difference in explaining why a precarious projectariat emerged in Slovenia rather than France is that, in Slovenia, the state's capacity to organize project transactions was weakened, making the organizational field more vulnerable to destabilizing transnational influences. Slovenia still lacks effective ESF project-supporting organizations and willing service providers for the new agenda to organize this recently introduced transaction. In the context of austerity this weakened state's capacity destabilizes the whole social protection field and introduces insecure project-based organization to previously secure permanent public sector organizations. The problem was 
not a domestic story of deteriorating quality of jobs and services, followed by tighter management; instead, the EU-level drove this weakness through ESF conditionality imposed at a difficult time, and post-crisis austerity pressures which compounded lower levels of social spending compared to France. The ESF imposed stringent new requirements in organizing transactions, which Slovenia struggled to meet, in part because it was a new member state. Hence, in issuing tenders, it relied on new organizational types over whom it had weak authority, while existing structures were made more fragile by ESF conditionality and its project-based organization.

The French state's transaction organizing function, by contrast, was not overwhelmed. Weaker austerity pressures and stable transaction organizer-provider relationships meant that the organization of transactions evolved through dialogue, which could incorporate ESF compliance without significant disruption. The upshot was that in France, social work professionals in the social protection field tended to retain relatively secure professional status and felt able to count on the renewal of funding settlements (and hence jobs) at the end of projects. In France, the main sources of perceived potential insecurity were national political trends rather than the EU level. Findings are summarized in table 2 . 
(Table 2 about here.)

The theoretical implications of our findings concern the discussion in organization studies of projectification, in particular the effects of the organization of the transaction on project tasks, role structures, temporality, and institutional context. ESF funding has transformed the nature of the task in Slovenia by spreading the idea of 'active inclusion', while French policymakers have succeeded in selling their homegrown practices of insertion in these terms. ESF funding has altered role structures in Slovenia by opening the field to new providers, while in France local policymakers have found ways to protect incumbent local nonprofit providers and their staff. ESF funding has disrupted timeframes in Slovenian social services by precluding providers from using permanent employment contracts, while in France the protections for the local providers allow for continuity in the face of contract turnover. Finally, ESF funding - together with austerity - has altered the nature of welfare services in Slovenia by de-funding traditional services and shifting what resources remain to new kinds of services, while in France funders and providers have so far adjusted incrementally to austerity within the existing institutional framework. It remains to be seen whether Macron's liberalizing agenda will force change and how our research site compares to other parts of France. 
We draw on two strands of institutional theory that have influenced the projectification literature - transaction cost economics and field theory - but contributing to them is beyond the scope of this paper. Typically, the transaction-cost approach sees transaction governance as driven by efficiency maximization with parameters set by the task; an important puzzle for transaction cost economics is the reversal of this causal chain, in which the task itself is altered by the governance of the transaction. Similarly, the effects of transactions on organizational fields are important empirically, but remain unexamined in field theory. While this paper suggests these avenues for theoretical development, delivering on this potential is for future research.

Our study raises the question of whether this connection between transactions and precarious project dynamics applies in organizational fields other than social services. Two key features of transactions highlighted in our argument point to broad relevance. First, they are non-spontaneous, since they are determined by an administrative agency. Second, they have a strong transnational dimension: austerity intensifies resource scarcity and ESF conditionality increases administrative requirements. Both of these conditions could apply under public procurement, including public works, military contractors, IT infrastructure, and other health and social services. We could also observe interesting parallels in the global supply chains of firms in highly concentrated sectors such as automotive and 
commercial aircraft manufacturing and with technology firms seeking monopoly by organizing exchange on electronic platforms.

For purposes of our argument, we assume that the transaction organizer is interested in maintaining a stable organizational field among project-based organizations delivering the services. This is often realistic: public funders commonly pursue this goal through living wage ordinances or by building social and environmental standards into their purchasing practices (Jaehrling, 2015). Economic sociologists assume more generally that market participants are interested in stabilizing exchange (Ahrne et al, 2015). But this is not always the case: the disruptive effects of marketization in social services has been cited both as a danger (Greer et al 2017) and benefit (Le Grand, 2003). Where government funders do seek to be a stabilizing influence on organizations and employment, however, our findings reveal the importance of their ability to organize project transactions. 


\section{References.}

Ahrne, G., Aspers. P., and Brunsson, N. (2015). The organization of markets. Organization Studies, 36, 7-27.

Bach, S., \& Bordogna, L. (2013). Reframing public service employment relations: the impact of economic crisis and the new EU economic governance. European Journal of Industrial Relations, 19, 279-294.

Baines, D. (2004). Caring for nothing: Work organization and unwaged labour in social services. Work, Employment and Society, 18, 267-295.

Bakker, R., Boroş, S., Kenis, P., \& Oerlemans, L. A. (2013). It's only temporary: time frame and the dynamics of creative project teams. British Journal of Management, 24, 383397.

Bakker, R. M., DeFillippi, R. J., Schwab, A., \& Sydow, J. (2016). Temporary organizing: Promises, processes, problems. Organization Studies, 37, 1703-1719.

Bechky, B. (2006). Gaffers, gofers, and grips: Role-based coordination in temporary organizations. Organization Science, 17, 3-21.

Bezes, P. and Le Lidec, P. (2011) 'L'hybridation du modèle territorial français', Revue française d'administration publique, 136, 919-42.

Blyth, M. (2013). Austerity: The history of a dangerous idea. Oxford University Press.

Bohle, D. and Greskovits, B. (2012). Capitalist diversity on Europe's periphery. Ithaca: Cornell University Press.

Bubbico, R. and De Michelis M. (2011). The financial execution of the cohesion funds. Regional focus, 3.

Brodkin, E. Z. (2008). Accountability in street-level organizations. International Journal of Public Administration, 31, 317-336.

Christopherson, S. (2002). Project work in context: regulatory change and the new geography of media. Environment and Planning A, 34, 2003-2015. 
Commission, European (2014), 'A map of social enterprises and their ecosystems in Europe',

(http://ec.europa.eu/social/main.jsp?langId=en\&catId=89\&newsId=2149\&furtherNews=ye s: European commission).

Cunningham, I., \& Nickson, D. (2011). A gathering storm: re-tendering and the voluntary sector workforce. International Journal of Public Sector Management, 24, 662-672.

Dille, T., \& Söderlund, J. (2011). Managing inter-institutional projects: The significance of isochronism, timing norms and temporal misfits. International Journal of Project Management, 29(4), 480-490.

Doellgast, V., Lillie, N., \& Pulignano, V. (Eds.). (2018). Reconstructing solidarity: Labour unions, precarious work, and the politics of institutional change in Europe. Oxford University Press.

Dörrenbächer, N. (2017). Europe at the frontline: analysing street-level motivations for the use of European Union migration law. Journal of European Public Policy, 1-20.

Ferge, Z. (2000). 'Social security reform: is it a different issue for accession countries? (draft)', Paper prepared for the conference organised by CEPII (Paris) and CEPS (Brussels) on the Economic and Social Dimensions of EU Enlargement. Brussels, 16 November 2000.

Finn, D. (2015). Welfare to work devolution in England. Joseph Rowntree Foundation.

Fretel, A. (2008). L'association comme réponse à la question sociale du XIXe au XXe siècle: d'un registre libéral à l'alliance à l'Etat social. Revue de la régulation. Capitalisme, institutions, pouvoirs, 2, 1-22.

Gerven, M., Vanhercke, B., \& Gürocak, S. (2014). Policy learning, aid conditionality or domestic politics? The Europeanization of Dutch and Spanish activation policies through the European Social Fund. Journal of European public policy, 21, 509-527.

Glaser, B. G., \& Strauss, A. L. (2017). Discovery of grounded theory: Strategies for qualitative research. London: Routledge.

Grabher, G. (2004). Temporary architectures of learning: Knowledge governance in project ecologies. Organization studies, 25, 1491-1514. 
Greer, I. and Doellgast, V. (2017). Marketization, inequality, and institutional change. Toward a new framework for comparative employment relations. Journal of Industrial Relations, 59, 192-208.

Greer, I., Breidahl, N. K., Larsen, F., \& Knuth, M. (2017). The Marketization of Employment Services: The Dilemmas of Europe's Work-First Welfare State. Oxford University Press.

Greer, I., Schulte, L., and Symon, G. (forthcoming). Creaming and parking in marketised employment services. An Anglo-German comparison. Human Relations.

Godenhjelm, S., Lundin, R. A., \& Sjöblom, S. (2015). Projectification in the public sectorthe case of the European Union. International Journal of Managing Projects in Business, 8 , 324-348.

Heyes, J. and Lewis, P. (2015). Relied upon for the heavy lifting: can employment protection legislation reforms lead the EU out of the jobs crisis? Industrial Relations Journal, 46, 81-99.

Hooghe, L., \& Marks, G. (2001). Multi-level governance and European integration. Rowman \& Littlefield.

Huguenot-Noël, R., Hunter, A., \& Zuleeg, F. (2017). Can the EU structural funds reconcile growth, solidarity and stability objectives? A study on the role of conditionalities in spurring structural reforms and reducing macroeconomic imbalances. EPC Issue Paper No. 83, October 2017.

Jantz, B., Klenk, T., Larsen, F., \& Wiggan, J. (2015). Marketization and varieties of accountability relationships in employment services: Comparing Denmark, Germany, and Great Britain. Administration \& Society, 50, 321-345

Jaehrling, K. (2015). The state as a 'socially responsible customer'? Public procurement between market-making and market-embedding. European Journal of Industrial Relations, 21, 149-164.

Kalleberg, A. L. (2009). Precarious work, insecure workers: Employment relations in transition. American sociological review, 74, 1-22. 
Karmowska, J., Child, J., \& James, P. (2017). A contingency analysis of precarious organizational temporariness. British Journal of Management, 28, 213-230.

Keune, M. and Payton, N. (2017). Active Inclusion at the European Level: Actors, Discourses and Policies. Amsterdam: Amsterdam Institute for Advanced Labour Studies.

King, G., Keohane, R. O., \& Verba, S. (1994). Designing social inquiry: Scientific inference in qualitative research. Princeton: Princeton University Press.

Lavitry, L. (2015). Flexibilité des chômeurs, mode d'emploi: les conseillers à l'emploi à l'épreuve de l'activation. Paris: PUF.

Lebar, L, et al. (2014). Evalvacija programa Spodbujanje neaktivnih oseb, ki so dalj časa oddaljene od trga dela, za njihovo vrnitev oziroma ponovni vstop na trg dela s poglobljeno individualno in skupinsko obravnavo. Ljubljana: NISV.

Lipsky, M. (1980). Street level bureaucracy: Dilemmas of the individual in public services. New York: Russell Sage Foundation.

Ligthart, R., Oerlemans, L., \& Noorderhaven, N. (2016). In the shadows of time: A case study of flexibility behaviors in an interorganizational project. Organization Studies, 37, 1721-1743.

Lundin, R. A., Arvidsson, N., Brady, T., Ekstedt, E., \& Midler, C. (2015). Managing and working in project society. Cambridge: Cambridge University Press.

Marchington, M., Grimshaw, D., Rubery, J. and Willmott, H. (2005) Fragmenting Work: Blurring Organizational Boundaries and Disordering Hierarchies. Oxford: Oxford University Press.

Midler, C. (1995). "Projectification" of the firm: the Renault case. Scandinavian Journal of Management, 11(4), 363-375.

Munck af Rosenschöld, J., \& Wolf, S. (2017). Toward projectified environmental governance? Environment and Planning A, 49, 273-292. 
Müller, R., Pemsel, S., \& Shao, J. (2014). Organizational enablers for governance and governmentality of projects: A literature review. International Journal of Project Management, 32, 1309-1320.

Novak, M. and Rihar-Bajuk, K. (2007). Slovenia, in Bob Deacon and Paul Stubbs (eds.), Social policy and international interventions in South East Europe. London: Edward Elgar, 45-61.

Palier, B. (2010). A long goodbye to Bismarck? The politics of welfare reform in continental Europe. Amsterdam University Press.

Peticca-Harris, A., Weststar, J., \& McKenna, S. (2015). The perils of project-based work: Attempting resistance to extreme work practices in video game development. Organization, $22,570-587$.

Ranald, P. (2002). Where are the jobs in the job network? Competitive tendering of employment services, in Peter Fairbrother, Michael Paddon, and Julian Teicher (eds.) Privatisation, Globalisation and Labour (Federation Press), 158-181.

Rothstein, B. (1998). Just institutions matter: the moral and political logic of the universal welfare state. Cambridge University Press.

Samaluk, B (2017). Austerity stabilised through European funds: the impact on Slovenian welfare administration and provision. Industrial Relations Journal, 48, 56-71.

Schulte, L., Umney, C., Greer, I., Iankova, K., \& Symon, G. (forthcoming). Insertion as an alternative to workfare: Active labour market schemes in the Parisian suburbs. Journal of European Social Policy.

Smolej-Jež, S., et al. (2017), 'Spremljanje izvajanja programov socialnega varstva (za leto 2016)', (Ljubljana: ISV).

Stinchcombe, A. L. (1959). Bureaucratic and craft administration of production: A comparative study. Administrative science quarterly, 4, 168-187.

Sydow, J., Lindkvist, L., and DeFillippi. R. (2004) Project-based organizations, embeddedness and repositories of knowledge. Organization Studies, 25, 1475-1489. 
Trbanc, M. (2015), 'Podlage za pripravo in zagon programov socialne aktivacije', (Ljubljana: Inštitut Republike Slovenije za socialno varstvo).

Umney, C., Greer, I., Onaran, Ö. and Umney, C. (Forthcoming). The state and class discipline: European labour market policy after the financial crisis. Capital and Class.

Van Gestel, N and Hillebrand, B (2011) 'Explaining stability and change: the rise and fall of logics in pluralistic fields' Organization Studies 32: 231-252

Verschraegen, G., Vanhercke, B., \& Verpoorten, R. (2011). The European Social Fund and domestic activation policies: Europeanization mechanisms. Journal of European Social Policy, 21, 55-72.

Whitley, R. (2006). Project-based firms: new organizational form or variations on a theme?. Industrial and corporate change, 15, 77-99.

Williamson, O. E. (1985). The Economic Institutions of Capitalism: Firms, markets, relational Contracting. New York: The Free Press.

Zaviršek, D. (2008) Engendering social work education under state socialism in Yugoslavia, British Journal of Social Work, 38, 734-50.

Zeitlin, J., \& Vanhercke, B. (2017). Socializing the European Semester: EU social and economic policy co-ordination in crisis and beyond. Journal of European Public Policy, 126.

Zimmermann, K. (2016). Local Responses to the European Social Fund: A Cross-City Comparison of Usage and Change. JCMS: Journal of Common Market Studies, 54, 14651484. 


\begin{tabular}{|c|c|c|}
\hline \multicolumn{3}{|c|}{ Table 1. Interviews and interviewees } \\
\hline & Slovenia & France \\
\hline \multirow{5}{*}{$\begin{array}{l}\text { Policy- } \\
\text { makers }\end{array}$} & 1. $04 / 2015$ & 1. $03 / 2012$ \\
\hline & 2. $05 / 2015$ & 2. $12 / 2016 *$ (follow-up with policymaker 1 ) \\
\hline & 3. $06 / 2015$ & 3. $06 / 2012 *$ \\
\hline & 4. $10 / 2015^{*}$ & 4. $12 / 2016 * *$ \\
\hline & 5. $10 / 2015^{* *}$ & \\
\hline \multirow[t]{18}{*}{ Providers } & Management & Managers \\
\hline & 1. $05 / 2014 \mathrm{NGO}$ & 1. $04 / 2012 \mathrm{NGO}$ \\
\hline & 2. 06/2014 NGO & 2. 01/2015 Public sector \\
\hline & 3. 05/2014 NGO & 3.-4. 01/2015 NGO \\
\hline & 4. 06/2014 NGO & \\
\hline & 5. 07/2014 Public sector & Workers \\
\hline & 6. $10 / 2015$ Public sector & 5. 05/2011 Private sector \\
\hline & & 6.-7.03/2012 Private sector \\
\hline & Workers & 8. 05/2012** Public sector \\
\hline & 7. 05/2014*NGO & 9. 05/2012* Public sector \\
\hline & 8. 05/2014 Public sector & 10. 03/2015* Public sector \\
\hline & 9.- 06/2014 NGO & 11.-14. 03/2015 NGO \\
\hline & 10. $06 / 2014$ NGO & 15.-17. 04/2015 NGO \\
\hline & 11. $10 / 2015$ Public sector & \\
\hline & & Workers and managers \\
\hline & Worker and manager & 18. 03/2012* Private sector \\
\hline & 12. $05 / 2014 * N G O$ & \\
\hline & 13. $10 / 2015^{* *}$ Public sector & \\
\hline \multirow[t]{10}{*}{ Other } & Trade unionists & Academics 1.-3. 12/2011 \\
\hline & 1. $06 / 2015^{*}$ & Business association 04/2012 \\
\hline & 2. $08 / 2015$ & NGO umbrellas $1.04 / 2012$ \\
\hline & 3. $09 / 2015^{*}$ & 2. $09 / 2014$ \\
\hline & 4. 09/2015 & \\
\hline & 5 10/2015 & \\
\hline & NGO umbrella 05/2014 & \\
\hline & Social work student 05/2015 & \\
\hline & European Commission 06/2015 & \\
\hline & Social movement activist $10 / 2015$ & \\
\hline
\end{tabular}


. Total $\quad .36$ interviewees, 27 interviews . . 36 interviewees, 28 interviews

. Most interviews were with 1 interviewee; ${ }^{*}$ denotes 2 and ${ }^{* *}$ denotes 3 interviewees. 
Table 2. The two country cases compared

\begin{tabular}{|c|c|c|}
\hline & $\begin{array}{c}\text { France } \\
\text { (Seine-Saint-Denis) }\end{array}$ & Slovenia \\
\hline Population & $\begin{array}{c}70 \mathrm{~m} \\
(1.6 \mathrm{~m})\end{array}$ & $2 m$ \\
\hline Shared characteristics & \multicolumn{2}{|c|}{$\begin{array}{l}\text { ESF funding for 'active inclusion' projects } \\
\text { Bismarck-style welfare state } \\
\text { Austerity pressures, EU macro-level governance }\end{array}$} \\
\hline $\begin{array}{l}\text { Capacity of manage } \\
\text { transaction }\end{array}$ & High & Low \\
\hline Experience with EU funding & High & Low \\
\hline Austerity measures & Slow and selective & Sudden and broad \\
\hline Precarious projectariat? & No & Yes \\
\hline Job security & Comparatively high and stable & Shift to insecurity \\
\hline $\begin{array}{l}\text { Occupational status of front- } \\
\text { line workers }\end{array}$ & Comparatively high and stable & Downgrading \\
\hline
\end{tabular}

